\title{
For the recuperation of the process of change for the people and with the people
}

\author{
Colectivo Manifiesto 22 de Junio
}

Published online: 18 September 2011

(C) Springer Science+Business Media B.V. 2011

Editor's note:

The following is a manifesto by the Colectivo Manifiesto 22 de Junio, a confluence of important social movement activists, former public officials and intellectuals who supported the rise to power of Evo Morales and those who foresaw, from the beginning, the actual state of affairs in Bolivia. As the following attests, they have decided to jointly make continuing public analysis of the limits of the actions of the Morale's administration in relation to the deepening of the process of social transformation.

Brothers and sisters,

We who sign this manifesto are not attributing representation to anyone. We are simply assuming the moral obligation to give our honest and committed word in the face of the difficult moments our country is now living, identifying ourselves with what many Bolivians feel and think.

When in the year 2000, Bolivians broke with the forms of politics and economy to which all governments had condemned us, stripping us of almost all that is material and spiritual, we decided to stand up and change things by ourselves. So we defeated the common enemies of our people and of other peoples like ours: the colonial state, bad governments, financial institutions like the IMF and World Bank, transnational corporations, oligarchies, political parties, and the repressive apparatus.

Our weapons were sticks and stones, but before all else, the capacity for indignation and struggle, recovered in the face of the contempt with which they governed and oppressed us, always in our own name and for the benefit of a foreign privileged elite and transnational capital. Our method was mobilization and so responded the social movements and the indigenous peoples and nations. We

Colectivo Manifiesto 22 de Junio $(\square)$

La Paz, Bolivia 
practiced that democracy that we have always wanted: direct, participatory, without intermediaries, in assemblies and councils, in the plazas, the streets, the unions, the communities, the families, and the territories, deliberating, deciding, and executing what we had decided. We changed the course of the plunder of our commons and our national patrimony constructed by the generations of our fathers and grandfathers, mothers and grandmothers, and we decided, as in 2000, 2003, and 2005 , that our destiny should be well-being, dignity, and liberty for those that live in this territory without exclusion or discrimination. We defeated the neoliberal project, the exclusive, mercantilist, and corrupt circus politics and brought back an ethical form of politics, understanding it as our collective capacity to construct a common destiny.

It was such that the common working people of the countryside and the city, the citizens, with their struggle and their hope and from their communities and grassroots organizations opened the process of change, giving it the purpose of profoundly transforming the unjust reality that has always prevailed and of constructing a new state and a new society where every citizen can live together in equality, justice, and fraternal harmony among and with the great community of life that is our Mother Earth.

Today, in 2011, the fifth year of the government of Evo Morales, we all ask ourselves: How are we? What has happened? What is the situation? What is the future of the process of change that we have opened among all of us and in which we have deposited our hopes for a better collective future?

\section{The economy}

Today, the large majority of our people basically find themselves in the same situation of poverty, precariousness, and anguish in which they have always been. It would seem that those who have improved are those that had always been well: the bankers, transnational oil and mining companies, the smugglers, and the narcotraffickers. The gasolinazo of December 26, 2010 was evidence to the economic management of this government that reproduces and restores the old structures that have historically maintained poverty and oppression in this country and not the construction of new, just, and liberating structures that is the mandate of the Bolivian people.

\section{Five years after the nationalization, the transnationals still control our hydrocarbon resources}

The nationalization decreed May 1, 2006, in order to be real and effective, had to be accomplished in a rapid sequence of actions centered on the material expropriation of hydrocarbons at every level of the productive process on part of the Bolivian state, as represented by YPFB (the state-owned petrol company of Bolivia). However, to this day, this process has been reduced to only the recovery of the secondary sectors of transportation and refining. Five years after its re-founding, 
YPFB does not operate, save for one possible irrelevant exception, even one hydrocarbon field in production, and it does not show the will to impose its strategy nor promote the national interests in the face of foreign contractors as would correspond to the exercise of the inalienable right to ownership by the Bolivian state and would honor the discourse, "partners, not bosses." The relegation of the national interest has arrived at an inconceivable situation of acquiring, at a high price, the majority stake in a particular hydrocarbon company only to cede to the transnational partner the condition of operator and consequently, effective control over the productive process.

The transnational oil companies, supposedly nationalized, have benefited from unjust and exorbitant compensation charged to YPFB. For example, Transredes was compensated with around \$US 241 million, compensations for investments financed by YPFB. It received this compensation even though it failed and caused grave economic damage to the Bolivian state in previous years. To other foreign oil companies, YPFB is returning to them the cost, estimated globally at SUS 1.5 billion, of past investments that have entrenched the power of these oil companies and secured future benefits. To all foreign contractors, YPFB is returning by way of "recoverable costs" large quantities of money that in 2010 alone amount to \$US 640 million. This concept, with its broad scope and ambiguity, could be applied to a large variety of situations, many of which are lacking in legitimacy and are beyond the effective control of YPFB. The foreign oil companies benefit as well from the unjust return of transaction taxes, despite the fact that this tax ultimately falls on the consumers. Finally, some of these businesses, such as PETROBRAS, have come to be illegitimately favored with the ability to export Bolivian gas of a high energetic value that is not properly recognized in their own purchase price.

Notwithstanding all of the unjust privileges that they continue to enjoy and the effective control over the productive process that they continue to maintain, 5 years after the nationalization, the transnational oil companies contributed SUS 1.528 billion (in royalties and IDH) in 2010. But, if we subtract the SUS 640 million that the oil companies demand that YPFB pays them for recoverable costs in that same year, the result is that the effective contribution is reduced to SUS 888 million, while other businesses contributed SUS 857 million in taxes to the utilities in the same year. That is to say, all of the businesses contributed SUS 1.746 billion in 2010. Meanwhile, consumers and citizens, the people, contributed around \$US 2.3 billion through a series of taxes without including property taxes. In other words, the people contribute a greater amount than the oil companies to sustain the state.

In contrast, YPFB suffers the constant de-capitalization from being responsible for payment of compensation, the return of recoverable costs, investments, and the transaction taxes for transnational oil companies. Also, YPFB has been responsible for supporting the weak economy through its payments towards the Bono Juancito Pinto, Bono Juana Azurduy, and the Renta Dignidad government programs to support primary education, maternal care for the prevention of infant mortality, and elderly economic support. At the same time, YPFB suffers from grave operational weaknesses. It was revealed as such when in a relative effort to support its perpetual 
de-capitalization, \$US 1 billion was sent to it from international reserves, and in 2 years, it did not have the capacity to invest even a small proportion of it.

While the power of the transnational oil companies has been restructured only on the surface allowing them to still effectively conserve their control over Bolivian hydrocarbons, YPFB has been re-founded only to be crushed by the weight of debts and payment of government programs, problems that are compounded by its overwhelming incapacity for management and its clientelistic nature that in the past had produced its ruin. Therefore, 5 years after its re-founding, YPFB is weak and a marginal business in the productive process of hydrocarbons and has not overcome in an effective and essential manner the residual condition to which it was condemned by neoliberalism and is not capable of developing a business strategy that permits the effective national expropriation of hydrocarbons.

\section{Bolivia finances transnational financiers with its international reserves}

As a show of the good health of the national economy and the success of his economic policies, Evo Morales and his government point to the existence of international reserves that express the savings of the country and have grown to \$US 10.7 billion, a figure never before realized. However, the benefit that the country and particularly the social sectors receive from these aforementioned reserves is scarce and doubtful, while it is evident that significant benefits are received by transnational financial capital.

In effect, an important part of the reserves has been directed towards the purchase of bonds from foreign banks and governments like those of the United States and Portugal. In the first half of 2010 alone, Bolivia invested \$US 734 million in United States Treasury bonds at an average interest rate of $2 \%$. The result was that the supposedly anti-imperialist and anti-capitalist government of Bolivia finances with the country's domestic savings the very same treasury of the empire.

Additionally, the government of Bolivia, during the first half of 2010, bought bonds from the Bilbao Vizcaya-Argentaria Bank of Spain at a value of SUS 1.29 billion. In this case, the Bolivian investment receives an extraordinarily low interest rate at around $0.25 \%$, while the concessional credit that the country receives from the World Bank requires an interest rate of $0.5 \%$, credit provided by the Andean Development Corporation requires $2.5 \%$, and the credit of solidarity from Venezuela requires $2 \%$. That is to say that the government of Evo Morales uses the savings of the Bolivian people to give concessional credits to a transnational bank at an interest rate 8 times less than the rate for the credit of solidarity that Venezuela provides to Bolivia. The "anti-capitalist" and "anti-imperialist" government of Evo Morales is much more generous and in solidarity with a transnational bank, the core of strength and aggression of global capital, than President Hugo Chavez is with Bolivia. Considering the importance and availability of the international reserves, it must also be held in mind that around \$US 4 billion of these reserves must be directed towards Bolivian foreign imports and also must be compared with the external debt, which presently is around \$US 3 billion. 
In sum, amidst a high-sounding anti-capitalist and anti-imperialist discourse, the government of Evo Morales has financed at an incredibly low interest rate rich countries and transnational banks with more than \$US 2.5 billion of the precious domestic savings from one of the poorest countries of the continent. At the same time, the public resources invested in the productive sectors of the county have been insignificant and absolutely insufficient, in spite of the fact that among those sectors exist many ventures that would pay out much more than the miserable interest rates paid by the US. Treasury and the Bilbao Vizcaya Bank. Because of the scarce public investment for the general productive development of the country, important opportunities have been lost to diversify the economy towards productive sustenance, self-sufficiency and food sovereignty, diminish technological dependence, and reconstruct and effectively strengthen the country's strategic industries. Even more serious and frustrating for the process of change is the desertion of the revolutionary purpose of constructing and developing a social and community sector of the economy designed to form the axis of a new economic model of real equality and increased social inclusion that would lead to the new society that Bolivians long for.

Ultimately, we have been obstructed from moving beyond the extractivist model to which we have historically been condemned by colonialism. Further, the model has reinforced its persistence in strengthening the chains of our dependence on the global capitalist system, subordinating us to a division of labor and to the conditionalities of international trade, and transferring our natural resources and goods in the interests of the accumulation of transnational capital. On the contrary, what is in accord with the horizon established by the new Constitution and the opening of routes for a transformative and emancipatory transition is leaving behind the extractivist model and economic dependence and constructing a productive model that generates new social relations of production based on solidarity, complementarity, and reciprocity; a new socioeconomic model that in the framework of a plural, integrated, and complimentary economy leads us to a society of living well and the construction of another world.

\section{More debt to be carried on the shoulders of the Bolivian people}

Given that the state has fallen into a fiscal deficit due to rentier policies, the growth of bureaucracy, and large concessions to transnationals companies, the government has accelerated the increase of the public debt. In 2011 alone, the credit of multilateral agencies of other countries amounted to around \$US 1.5 billion in net indebtedness. Consequently, the external debt reached around \$US 3 billion by the end of 2010. The other component of state financing, the internal debt, has also experienced significant growth, increasing to more than \$US 4.5 billion in 2010. In sum, the debt of the Bolivian state has already surpassed \$US 7.5 billion.

But for the government, this significant indebtedness does not appear to be sufficient nor represent any problem, so the government has decided to take on much more debt. Thus, the economic ministry has announced that it will issue bonds of the Bolivian government of an amount of \$US 5 billion in 2011 alone and offer 
them on the international market. Continuing with this policy is a serious assault on the national economy. If new projections of indebtedness materialize, Bolivia will not be able to complete payment of its debt, which has been a painful experience for the whole continent. The weight of this debt will suffocate and crush all of our initiatives and efforts toward sovereign development.

The government intends to obtain new revenues at the cost of the must vulnerable such as the neoliberals of the past have done. This is why the government has identified resources in workers' insurance and intends to use them against the will of their beneficiaries and without respecting the rights nor the autonomy of these institutions. In the same way, in the project outline for the New Hydrocarbon Law of 2011, a series of taxes on gross sales and others are formulated that would inevitably fall on the population that has already seen its income reduced by inflation. This is the shadow of a new, but much more obscured, gasolinazo that hangs overhead the Bolivian people.

\section{Politics}

Also within the political sphere, the construction of a participatory democracy has been the scene of great governmental capitulations and consequently, profound frustrations for the advance of the process of change.

The sovereign mandate of the Bolivian people, clearly expressed in the new Political Constitution of Bolivia (CPE-Constitucion Politica del Estado), establishes the supreme imperative of constructing the Plurinational State, conceived as the emancipatory integration of Bolivian society that expands and deepens democracy through its direct and community forms and the local and ethnic selfgovernment expressed in indigenous, departmental, municipal, and regional autonomy. The Plurinational State cannot violate the principles of traditional representative democracy, but instead must work towards its deepening and historical complementation, giving to the whole of society more rights, guarantees, liberty, and more than anything, participation in public decisions; in synthesis, more democracy. However, the government of Evo Morales has openly taken an antidemocratic choice, has cancelled the authentic construction of the Plurinational State, and has repeatedly violated the new CPE, which was recently approved by the hopeful will of the Bolivian people for a democratic transformation.

\section{Democratic principles have been violated}

The serious assaults on democracy and the violations of the new CPE started with the transgression of the elementary democratic principle of the separation of powers that resulted when the Executive Branch, with the servile complacency of the Legislative Assembly, unilaterally and arbitrarily named the principal authorities of the judicial branch. The subordination of the administration of justice to the will of the central government revealed by this action has generated justified doubts among the citizenry about the transparency and the legitimacy that will be given to the 
election of the judges by universal vote in accord with the constitutional norm. The aforementioned subordination has been thoroughly and shamefully confirmed by many surreptitious actions that the government has taken to direct different public institutions related with the administration of justice to the end of eliminating and repressing opposition and political dissidence. Beyond this profoundly authoritarian approach, this sustained behavior has had a particularly exculpatory impact on the truly corrupt of the traditional political elite by subjecting them to the same arbitrary treatment of those who are actual victims of unjust political repression by the judiciary consequently confusing everyone as among the victims. For others, the deliberate speed and weakness of principle with which the opposition is prosecuted or dismissed contrasts with the incredible slowness and inefficiency in the face of growing corruption among public officials.

At the same time, the government of Evo Morales has taken a strong authoritarian turn with the whole of society. So, while proclaiming to govern by obeying the will of the people, what it does in reality is govern from a narrow concentration of power over decisions about the collective future. Thus, all spaces that would permit effective social participation have been avoided or eliminated in the decision-making process, or they have been reduced to insignificant simulations of protocol. To the legitimate demands and mobilizations with which the popular sector exercises its rights and defends its interests, the government has responded with a slanderous dismissiveness, systematic intimidation, or violent and brutal repression. This has been particularly evident in the area of wage workers, where the struggle of workers against the precarious conditions they suffer and the nonrecognition of their social rights has been met with a government response of insult, intimidation, and repression. The government of Evo Morales has obscured its management and its actions, making knowledge inaccessible as well as participation by the citizenry, reducing the popularization of government to mediocre exercises in propaganda.

Finally, the authoritarian and repressive conduct of the government is combining with the reproduction of older practices of prebendalism and the corporate participation in the public administration, practices which characterize the oligarchic and colonial state, degrade the public function and debase popular and social organizations to political servitude. Today, as in the sad times of the decline of the Revolution of 1952 and the Military-Campesino Pact, there is a leadership always ready to aggressively confront, without more argument than the official dismissiveness, protesting workers, indigenous marches, or any other show of disconformity by the popular sector.

\section{The construction of the Plurinational State has been abandoned}

But if fundamental principles and institutions of representative democracy have been transgressed, the concrete constitution of new public institutions through which the Plurinational State must acquire real validity have been obstructed, distorted, postponed, or abandoned by the action or inaction of the government. The laws approved by the Plurinational Legislative Assembly without consultation of 
indigenous communities have ignored the word and spirit of the new Constitution and have condemned the project of the Plurinational State.

To begin, the Law of Electoral Rules has flagrantly violated the constitutional right of indigenous peoples to direct political representation profoundly undermining the plurinational character of the Legislative Assembly. The government has established a number of special limitations depriving real possibilities of direct political representation to various indigenous peoples of the national territory and denying all possibility of that to the indigenous peoples of Chuquisaca. Similarly and with regard to the Law of Autonomy and Decentralization for the establishment and functioning of indigenous autonomy, the government has established obstructive rules that ignore the practices of community democracy that are constitutionally recognized as well as ignore the pre-existence of the indigenous peoples to the Colony and the Republic, as is stipulated in the second article of the new Constitution. At the same time, the reform of the education system, a fundamental area for cultural emancipation and construction of a sense of plurinational citizenry, has not made any real or practical progress and if anything has experienced setbacks from the modest achievements of previous years. Finally, the Law of Jurisdictional Claims is colonial and racist, because it limits indigenous jurisdiction to a relegated position, as was the same during Colonialism, which contradicts the correct form of administration of justice according to the new Constitution, Covenant 169 of the ILO and the UN Declaration of Indigenous Rights.

\section{Mother earth has been abused and damaged}

The government of Evo Morales, which in international forums situates itself as the vanguard of the rights of Mother Earth and indigenous populations, has favored the seriously destructive and predatory advances of the extractivist model. These advances facilitate the destruction of the nature of the social sphere by destroying the capacities for harmony and cohesion, the cultural sphere by undermining communities and symbolic values, and finally, the ethical sphere by pushing the people to the abyss of moral decay. In this sense, unlike any other government of the recent past, the government has assumed in its totality the subimperial design of Brazilian capitalism in order to implement infrastructure megaprojects that are inadequate for local and national needs. Further, these projects imply additional external indebtedness and the consequential loss of sovereignty, the grave and irreparable damages to the ecosystem and to the exercise of the territorial rights of indigenous peoples.

In these efforts, the government has repeatedly violated a right provided to indigenous peoples by the new Constitution of previous and informed consultation when it intends to occupy or interfere with indigenous territory with public works or activities. Such is the case with the intention to build a highway with Brazilian capital through the middle of the National Park and Indigenous Territory of IsiboroSecure (TIPNIS), a project that has proceeded without the previous and informed consultation of the indigenous communities that have historically inhabited the territory and are its legal and legitimate owner. In the same direction, the 
government has pressed for the legalization of genetically modified products that are manipulated and commercialized under the monopolistic control of eight transnational companies and impedes the diversity and cycles of life and the complementary integration of living beings. Farming and indigenous communities, agrarian producers, and consumers are being subordinated to absolute dependence on the interests of transnational companies which in this case make them owners of the reproduction of life in order to commodify and commercialize it.

In the direction of the Water War, of the indigenous march for the Constitutional assembly, of the innumerable campesino and indigenous mobilizations for land and territory, of the victorious popular insurrections of April and September 2000, October 2003, and May and June of 2005 and of all the resistive gestures of the Bolivian population, we call on all Bolivians to recover the process of change for the people and to build with its constructive creative ability, a common destiny of justice, liberty, and dignity. In that framework, we propose an immediate opening of deliberative space of broad participation in which we seek to recover and redirect the process of change, while honestly and profoundly evaluating the situation of our country and constructing collectively and democratically the proposals and alternatives that will lead us to conquistar manana sonado. 